International Medical Society http://imedicalsociety.org

\title{
Suicidal Ideation Among Medical Students: an Integrative Review
}

Wendney Hudson de Alencar Fontes ${ }^{1}$, Yohanna Karen do Santos Silva", Francisco Matheus Prado Luna1, Raissa Maria Rolim Bem de Morais', João Paulo Gomes Feitosa², Fabione Gomes da Silva3, Filipe Costa Lisboa ${ }^{4}$, Maria do Socorro Vieira Gadelha ${ }^{5}$, Modesto Leite Rolim Neto 5

\section{Abstract}

Background: Suicide is more common among people who follow a medical career. This occurs because undergraduation course subjects students to psychologically strained situations, which can reduce their mental health and predispose them to suicidal ideation.

Objectives: To analyze the factors related to suicidal ideation among medical graduates, highlighting depression and personality traits. To check stigmas surrounding suicidal ideation.

Method: An integrative review study was carried out using the Scopus database (Elsevier). We selected studies published between 2014 and 2019, using two descriptors: "medical students" and "suicidal ideation".

Results and Findings: 139 scientific articles were selected, of which 10 met the eligibility criteria. Specific personality traits and depression predispose to suicide. Although the stigma of suicide and substance use is greater among men, female gender, poor financial status, and psychiatric disorders increase depression scores. Students close to graduation are more likely to cope with stress than others.

Limitations: The articles included in this work were produced using different methodologies and different measurement instruments. The prevalence of depression and suicidal ideation among students may be greater, given that stigma may favor the occurrence of response bias.
1 Faculdade de Medicina Estácio de Juazeiro do Norte, Estácio FMJ, Juazeiro do Norte, Ceará, Brazil.

2 Centro Universitário Leão Sampaio, UNILEÃO, Juazeiro do Norte, Ceará, Brazil.

3 Universidade Federal de Campina Grande, UFCG, Cajazeiras, Paraíba, Brazil.

4 Universidade Regional do Cariri, URCA, Crato, Ceará, Brazil.

5 Universidade Federal do Cariri, UFCA, Faculdade de Medicina, Barbalha, Ceará, Brazil.

Contact information:

Wendney Hudson de Alencar Fontes.

Æ hudsonfontes@hotmail.com 
Conclusion: Rates of suicidal ideation are very prevalent in medical students. To solve this problem, medical schools should take steps to prevent adverse situations.

\section{Keywords}

Suicidal Ideation; Mental

Health; Medical Students.

\section{Introduction}

Medical students are more predisposed to suicidal ideation than academics from other areas [1, 2]. This happens because during undergraduate students are subjected to stressful situations, to the requirement of new skills and to cognitive overload [1, 3]. These factors, by themselves, do not lead directly to ideation but play a fundamental role in predisposing individuals to depression whose outcome is suicidal ideation $[4,5]$.

Depression has as main characteristics, the reduction of interest in daily activities, feelings of guilt, suicidal thoughts and changes in biological rhythms. When not treated properly, these symptoms may predispose to the use of licit and illicit drugs, reduction of school performance, and suicidal ideation [1, 2]. Among medical students, those newly enrolled in the course have a higher prevalence of psychosomatic complaints and risk of mental disorder, and about $25 \%$ of first- and second-year students show signs of depression [6].

Another cause of suicidal ideation is stress. This factor has several causes, such as early academic life, changes in living and living conditions, and personal problems. In this sense, because of its workload and psychological pressure, medical school subjects the student to greater stress than other courses in the health area $[3,4,7]$.

In general, academic stress is associated with poorer mental health, leading to the emergence of reduced quality of life, musculoskeletal dysfunction, anxiety symptoms, and depression. However, although the pressures are similar, not all students deal with stress equally. Each student has their unique susceptibility and predisposition to face stressful situations and those most susceptible are the first to suffer earlier. This is probably related to the personality of each person $[3,4,7]$.

These personality traits (commitment, stability, discipline, social competence, and cooperation) affect performance during medical training. This is because some of them make the student more vulnerable to stress and worse mental health, favoring the development of depressive symptoms and suicidal ideation [6].

For all these reasons, the importance of suicidal ideation and its risk factors among medical students is recognized. With this in mind, it was made an integrative review aiming to answer the following question: what factors predispose medical students to suicidal ideation? To conduct the discussion of this work, two main objectives were established:

1) To analyze through the eligible studies, how depression and personality traits contribute to suicidal ideation.

2) To check for selected articles the stigmas surrounding suicidal ideation.

\section{Methods}

An integrative review about suicidal ideation in medical students was performed, using the Scopus (Elsevier) database. Two descriptors indexed in the Medical Subject Headings (MeSH), "medical students" and "suicidal ideation" were used, which were combined by the Boolean operator: AND. This study included studies published between 01/01/2014 and $01 / 14 / 2019$. Subsequently, we selected articles for 
Vol. 12 No. 10 doi: $10.3823 / 2604$ the sample adopting a strategy based on three stages: research in the electronic databases; selection and identification of eligible studies by the application of inclusion criteria; and extraction of data from included studies.

\section{The inclusion criteria}

a) articles published in full and available free online;

b) written in the English language.

Articles that did not address the topic under stu$d y$, editorials, reviews, short letters, researches and articles in other languages were included in the exclusion criteria.

\section{Results}

The database selected 139 scientific articles, of which 10 met the inclusion criteria (Figure 1). When applying the exclusion criteria, 20 articles were selected, of which only 10 papers remained, after examining them completely (Table 1).

\section{Discussion}

The beginning of medical graduation leads to a worsening of students' mental health, which increases the prevalence of depressive symptoms and suicidal ideation. Even over the years, mental health remains impaired, only improving when the students reach the final years of the course, as they learn to cope with stress and academic pressure $[2,4,7]$.

\section{Personality traits and suicidal ideation}

Chow et al., 2018 [6] suggest that personality traits influence the predisposition of suicide, in other words, they can increase or decrease the student's susceptibility to situations with a high level of pressure. Among these traits, social competence, stability, and autonomy reduce the risk of depression and suicidal ideation, while dominance increases them. However, it is not clear yet whether they are actually the cause or the consequence of suicidal ideation and depression $[4,6]$.

Personality characteristics can also serve as a measure for the development of PUI (problematic

Figure 1: Flowchart of selected studies.

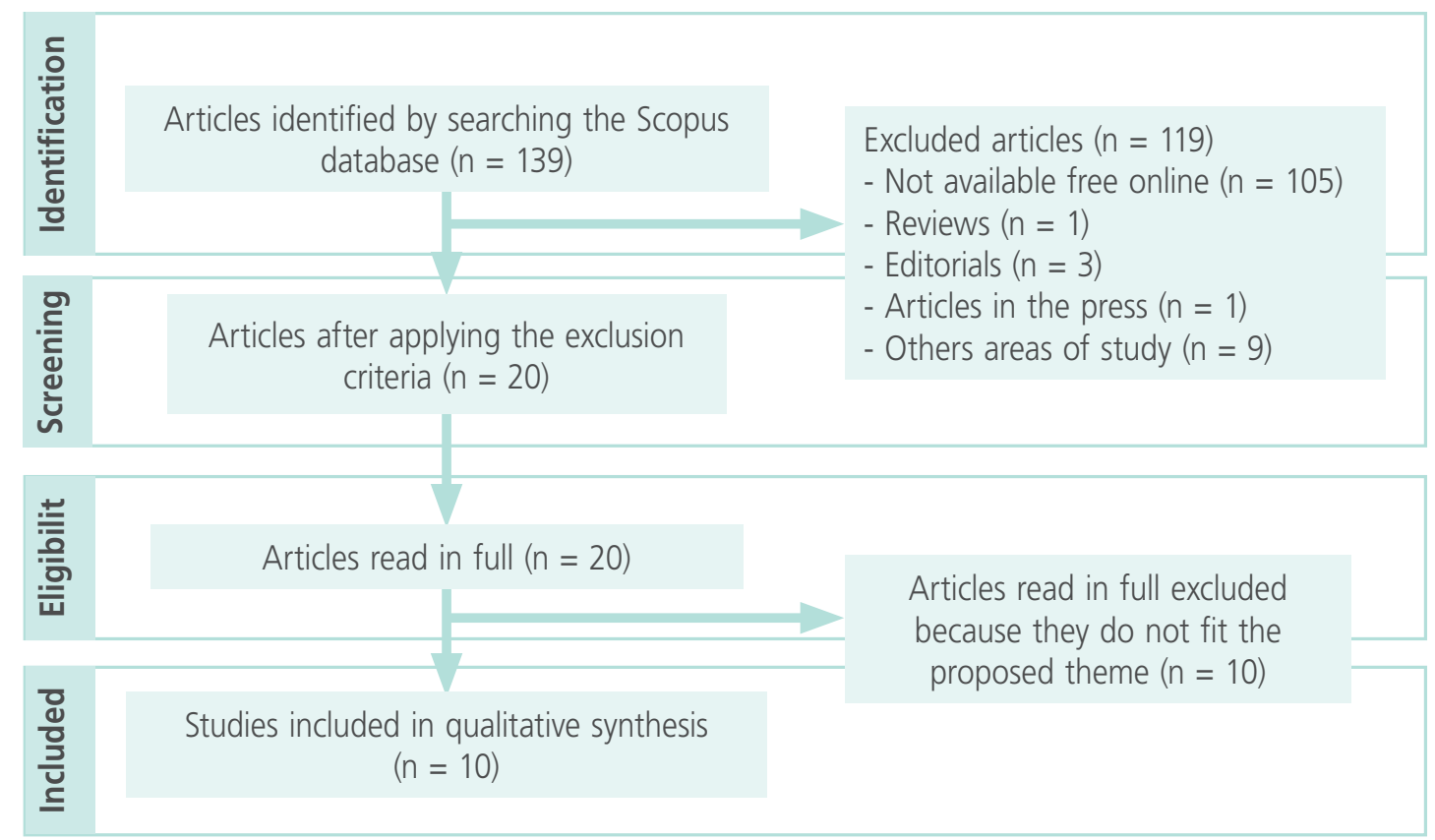


Table 1. Studies and Main Findings.

\begin{tabular}{|c|c|c|c|c|c|c|c|}
\hline Year & Author & Title & Journal & $\begin{array}{l}\text { Study } \\
\text { country }\end{array}$ & $\begin{array}{l}\text { Study } \\
\text { sample }\end{array}$ & $\begin{array}{c}\text { Type } \\
\text { of survey }\end{array}$ & Main Findings \\
\hline 2018 & $\begin{array}{c}\text { Chow } \\
{[6]}\end{array}$ & $\begin{array}{l}\text { The relationship between } \\
\text { personality traits with } \\
\text { depressive symptoms } \\
\text { and suicidal ideation } \\
\text { among medical students: } \\
\text { A cross-sectional study } \\
\text { at one medical school in } \\
\text { Germany }\end{array}$ & $\begin{array}{l}\text { International Journal } \\
\text { of Environmental } \\
\text { Research and Public } \\
\text { Health }\end{array}$ & Germany & $\begin{array}{l}251 \text { medical } \\
\text { students }\end{array}$ & $\begin{array}{l}\text { Cross-sectional } \\
\text { study }\end{array}$ & $\begin{array}{l}\text { Medical students who scored high on the Stability criteria had lower } \\
\text { odds of depressive symptoms and suicidal tendencies than those } \\
\text { with high scores on other work-related personality factors. Those } \\
\text { who scored more on the Dominance criteria had a greater chance of } \\
\text { depressive symptoms. }\end{array}$ \\
\hline 2018 & $\begin{array}{l}\text { Rivera- } \\
\text { Segarra } \\
\quad[9]\end{array}$ & $\begin{array}{l}\text { Suicide stigma among } \\
\text { medical students in } \\
\text { Puerto Rico }\end{array}$ & $\begin{array}{l}\text { International Journal } \\
\text { of Environmental } \\
\text { Research and Public } \\
\text { Health }\end{array}$ & Puerto Rico & $\begin{array}{l}123 \text { medical } \\
\text { students }\end{array}$ & $\begin{array}{l}\text { Cross-sectional } \\
\text { study }\end{array}$ & $\begin{array}{l}\text { Bivariate analyzes suggest that gender was significantly correlated } \\
\text { with suicide stigma. Hierarchical regression analysis suggested that } \\
\text { knowledge about the subject 'suicide' and the emotional reaction to } \\
\text { suicide were related to stigma of suicide. }\end{array}$ \\
\hline 2018 & $\begin{array}{l}\text { Berryman, } \\
\text { E.K. } \\
{[1]}\end{array}$ & $\begin{array}{l}\text { Self-reflected well-being } \\
\text { via a smartphone app in } \\
\text { clinical medical students: } \\
\text { Feasibility study }\end{array}$ & $\begin{array}{l}\text { Journal of Medical } \\
\text { Internet Research }\end{array}$ & New Zeland & $\begin{array}{l}29 \text { medical } \\
\text { students }\end{array}$ & $\begin{array}{l}\text { Quantitative } \\
\text { and qualitative } \\
\text { study }\end{array}$ & $\begin{array}{l}\text { A total of } 29 \text { participants were included, with a general agreement } \\
\text { of } 71 \% \text { at the study day level. Self-reported wellness scores were } \\
\text { associated with both positive and negative experiences described, } \\
\text { with most negative experiences being associated with about } 20 \% \\
\text { lower health scores on the day of the survey. }\end{array}$ \\
\hline 2017 & $\begin{array}{l}\text { Merlo, L.J. } \\
\quad \text { [7] }\end{array}$ & $\begin{array}{l}\text { Gender differences } \\
\text { in substance use and } \\
\text { psychiatric distress } \\
\text { among medical students: } \\
\text { A comprehensive } \\
\text { statewide evaluation }\end{array}$ & Substance Abuse & USA & $\begin{array}{l}1137 \\
\text { medical } \\
\text { students }\end{array}$ & $\begin{array}{l}\text { Cross-sectional } \\
\text { study }\end{array}$ & $\begin{array}{l}\text { Over } 70 \% \text { of the students recognized excessive alcohol } \\
\text { consumption. Nearly } 2 / 3 \text { of respondents reported decreased } \\
\text { psychological health from the beginning of medical school, with } \\
\text { women noticing greater reductions and higher levels of stress. More } \\
\text { than } 10 \% \text { of students endorsed "thoughts of committing suicide" } \\
\text { during graduation, and } 70.1 \% \text { thought they would benefit from } \\
\text { mental health care, although only } 39.8 \% \text { seek help. }\end{array}$ \\
\hline 2016 & $\begin{array}{c}\text { Coentre, R. } \\
{[2]}\end{array}$ & $\begin{array}{l}\text { Assessment of depression } \\
\text { and suicidal behaviour } \\
\text { among medical students } \\
\text { in Portugal }\end{array}$ & $\begin{array}{l}\text { International } \\
\text { journal of medical } \\
\text { education }\end{array}$ & Portugal & $\begin{array}{l}456 \text { medical } \\
\text { students }\end{array}$ & $\begin{array}{l}\text { Cross-sectional } \\
\text { study }\end{array}$ & $\begin{array}{l}\text { The prevalence of depression among medical students was } 6.1 \% \text { and } \\
\text { suicidal behaviour was } 3.9 \% \text {. The highest scores of depression were } \\
\text { observed in female medical students, students living alone, with poor } \\
\text { physical health, poor economic status, psychiatric diagnosis, family } \\
\text { history of psychiatric disorders or with high levels of anxiety. }\end{array}$ \\
\hline
\end{tabular}




\begin{tabular}{|c|c|c|c|c|c|c|c|}
\hline Year & Author & Title & Journal & $\begin{array}{l}\text { Study } \\
\text { country }\end{array}$ & $\begin{array}{l}\text { Study } \\
\text { sample }\end{array}$ & $\begin{array}{l}\text { Type } \\
\text { of survey }\end{array}$ & Main Findings \\
\hline 2016 & $\begin{array}{l}\text { Rosiek, A. } \\
\text { [3] }\end{array}$ & $\begin{array}{l}\text { Chronic stress and } \\
\text { suicidal thinking among } \\
\text { medical students }\end{array}$ & $\begin{array}{l}\text { International Journal } \\
\text { of Environmental } \\
\text { Research and Public } \\
\text { Health }\end{array}$ & Poland & $\begin{array}{l}100 \text { medical } \\
\text { students }\end{array}$ & $\begin{array}{l}\text { Cross-sectional } \\
\text { study }\end{array}$ & $\begin{array}{l}\text { The students' lives were full of stressors. Students at the end of } \\
\text { their undergraduate degree dealt better with stress than students } \\
\text { who are starting to graduate. Chronic stress had a strong impact } \\
\text { on mental health and suicidal thinking among students. }\end{array}$ \\
\hline 2015 & $\begin{array}{c}\text { Raeisei, A. } \\
\text { [4] }\end{array}$ & $\begin{array}{l}\text { The relationship } \\
\text { between personality } \\
\text { styles of sociotropy and } \\
\text { autonomy and suicidal } \\
\text { tendency in medical } \\
\text { students }\end{array}$ & $\begin{array}{l}\text { Global journal of } \\
\text { health science }\end{array}$ & Iran & 102 patients & $\begin{array}{l}\text { Descriptive- } \\
\text { correlational } \\
\text { study }\end{array}$ & $\begin{array}{l}\text { The results showed that there is an inverse and significant } \\
\text { relationship between autonomic style and suicide trends in } \\
\text { men, but there was no association between sociotropy and } \\
\text { suicidal tendencies in men. There was no significant relationship } \\
\text { between autonomy and sociotropic personality styles and suicidal } \\
\text { tendencies in women. }\end{array}$ \\
\hline 2015 & $\begin{array}{c}\text { Alpaslan, A.H. } \\
\text { [10] }\end{array}$ & $\begin{array}{l}\text { The association } \\
\text { between problematic } \\
\text { internet use, suicide } \\
\text { probability, alexithymia } \\
\text { and loneliness among } \\
\text { Turkish medical students }\end{array}$ & $\begin{array}{l}\text { African Journal of } \\
\text { Psychiatry [South } \\
\text { Africa] }\end{array}$ & Turkey & 328 people & $\begin{array}{l}\text { Cross-sectional } \\
\text { study }\end{array}$ & $\begin{array}{l}\text { The Problematic Use of Internet (PUI) was detected in } 6.4 \% \text { ( } n= \\
21 \text { ) of the participants. Its prevalence was significantly higher in } \\
\text { men than in women ( } p=0.009 \text { ). There was a significant positive } \\
\text { correlation between solitude, alexithymia, suicide probability, and } \\
\text { PIU. A significant positive relationship was also found between PUI } \\
\text { and discouragement, suicidal ideation and hostility. }\end{array}$ \\
\hline 2015 & $\begin{array}{l}\text { Mojs, E.H. } \\
\text { [5] }\end{array}$ & $\begin{array}{l}\text { Are students prone to } \\
\text { depression and suicidal } \\
\text { thoughts }\end{array}$ & $\begin{array}{l}\text { Archives of Medical } \\
\text { Science }\end{array}$ & Poland & $\begin{array}{l}1183 \\
\text { students }\end{array}$ & $\begin{array}{l}\text { Cross-sectional } \\
\text { study }\end{array}$ & $\begin{array}{l}\text { It was found that } 6.5 \% \text { of all participants }(n=77) \text { had depression } \\
\text { whereas } 1.5 \% \text { of them }(n=18) \text { reported suicidal thoughts. We } \\
\text { also observed the influence of such factors as gender, year, major } \\
\text { area of study, and financial status, on depression scores. Moreover, } \\
\text { depressive symptomatology was most frequent in subjects who } \\
\text { were only children, in freshmen and in students of psychology } \\
(11.5 \%, 13.2 \% \text { and } 16.7 \% \text { respectively) }\end{array}$ \\
\hline 2014 & $\begin{array}{c}\text { Sobowale, K. } \\
{[11]}\end{array}$ & $\begin{array}{l}\text { Depression and suicidal } \\
\text { ideation in medical } \\
\text { students in China: a call } \\
\text { for wellness curricula }\end{array}$ & $\begin{array}{l}\text { International } \\
\text { Journal of Medical } \\
\text { Education }\end{array}$ & China & $\begin{array}{l}348 \text { medical } \\
\text { students }\end{array}$ & $\begin{array}{l}\text { Cross-sectional } \\
\text { study }\end{array}$ & $\begin{array}{l}47 \text { of the } 348 \text { (13.5\%) students had moderate-severe depression. } \\
7.5 \% \text { of students reported suicidal ideation. The frequency of } \\
\text { depression and suicidal ideation did not differ between students in } \\
\text { the second and third years. Nearly } 30 \% \text { of depressed students had } \\
\text { suicidal ideation. Depression and suicidal ideation were strongly } \\
\text { correlated. Participants in the focus group reported only availability } \\
\text { of counseling services to off-campus students to struggling medical } \\
\text { students. No wellness curriculum has been established. }\end{array}$ \\
\hline
\end{tabular}


use of the internet). Lonely, introspective, and struggling people in interpersonal relationships use the internet as a way to meet their relationship needs and gain emotional support. In this sense, a study suggests a direct association between UPI, depression and suicidal behavior and that the UPI rate is $6.4 \%$ among medical students [10].

\section{Depression and suicidal ideation}

Coentre et al., 2016 [2] indicate that female gender, living alone, poor socioeconomic status or psychiatric disorders increase depression scores, which corroborates the findings of the study by Mojs et al., 2012. It also includes the history of personal problems [5].

Depression emerges as a poor adaptation to the stressors to which medical students are subjected. However, some students are more susceptible to depression than others, whether due to personality (as previously mentioned) or personal problems. As depression is strongly related to suicidal ideation, it may be suggested that students with greater emotional frailty have greater suicidal ideation [3, $5,11]$.

Medical students, otherwise, have higher levels of depression than the general population $(27.2 \%$ vs. $13.8 \%-21 \%)$. As with depression, they also have more elevated levels of suicidal ideation, with women having higher rates than men (2.27 and 1.42 times higher than the general population) [1]. Since this high prevalence of students remains beyond college, the medical profession becomes one with the highest rates of depression and suicidal behavior [2].

Rivera-Segarra et al., 2018 [9] state that stigma over suicide is a risk factor for attempts, in other words, those students who talk less about suicide are more likely to endorse suicidal thoughts and attempts. Although Rivera-Segarra et al., 2018 [9] state that less than $10 \%$ of students with depression seek counseling services when they need help, Merlo et al., 2017 [7] indicates this number is about $40 \%$.
In any case, this is known to be due to a lack of knowledge about suicide, possible emotional reactions to a person with ideations, and some cultural values (for example, chauvinism). Therefore, stigma is more frequent in males and in those who have little knowledge about the subject [9]. In this sense, Merlo et al., 2017 [7] further states that the use of substances such as alcohol, marijuana, and other drugs are more frequent in men than in women.

It may be assumed, then, that because men are not very comfortable reporting their problems to others, they are more likely to use drugs, perhaps as a way of evading their depressive thoughts.

\section{Limitations of work}

The articles that were included in this work were made using different methodologies and different measurement instruments. In addition, it is unknown whether students have ever arrived in medical school with any psychiatric disorder, and undergraduate has sparked such problems or if the disorders have only started after college. This may justify difficulties in comparative data and some divergences in the statistical information found. A second limitation refers to the fact that the prevalence of depression and suicidal ideation among students may be greater, given that stigma may favor the occurrence of response bias.

\section{Conclusion}

Suicidal ideation is common among medical students, especially those with specific personality traits and a greater predisposition to depressive symptoms. These symptoms arise with a dysfunctional adaptation of the stressful situations of academic life, favoring the suicidal behavior, which occurs more frequently in women. As for stigma, it is very prevalent in medical students, since less than $10 \%$ of students with depression seek help. Among these students, men are more prominent. In view 
of these data, this study aims to highlight the high prevalence of suicidal ideation in students, and in the future, to plan and implement intervention proposals to promote the well-being of these students and avoid worse outcomes.

\section{Contributors}

Fontes WHA, Silva YKS, Luna FMP, Morais RMRB, Feitosa JPGF: Literature review, data interpretation and writing.

Silva FG, Lisboa, FC: Review of information, writing and translation of the manuscript into English.

Gadelha MSV, Rolim Neto ML: Guidance on the manuscript, study design, and methodological review of the manuscript.

All authors contributed to and have approved the final manuscript.

\section{Conflict of interests}

The authors declare there is no conflict of interests involving this work.

\section{Acknowledgements}

To the research group of the Federal University of Cariri (UFCA), Juazeiro do Norte Medical School - Estácio FMJ / National Council for Scientific and Technological Development (CNPq), and to the Teacher Training Center of the Federal University of Campina Grande.

\section{References}

1. Berryman EK, Leonard DJ, Gray AR, Pinnock R, Taylor B. Selfreflected well-being via a smartphone app in clinical medical students: Feasibility study. J Med Internet Res. 2018 Mar 07; 4(1):82-92.

2. Coentre R, Faravelli C, Figueira ML. Assessment of depression and suicidal behaviour among medical students in Portugal. Int J Med Educ. 2016 Oct 29; 7:354-63.

3. Rosiek A, Rosiek-Kryszewska A, Leksowski L, Leksowski K. Chronic stress and suicidal thinking among medical students. Int J Environ Res Public Health. 2016 Feb 15; 13(2):212-27.
4. Raeisei A, Mojahed A, Bakhshani NM. The Relationship between Personality Styles of Sociotropy and Autonomy and Suicidal Tendency in Medical Students. Glob J Health Sci. 2015 Mar 9; 7(3):345-50.

5. Mojs E, Warchol-Biedermann K, Głowacka MD, Strzelecki W, Ziemska B, Marcinkowski JT. Are students prone to depression and suicidal thoughts? Arch Med Sci. 2015 June 19; 11(3):605-61.

6. Chow WS, Schmidtke J, Loerbroks A, Muth T, Angerer P. The relationship between personality traits with depressive symptoms and suicidal ideation among medical students: A cross-sectional study at one medical school in Germany. Int J Environ Res Public Health. 2018 Jul 11; 15(7):1462-72.

7. Merlo LJ, Curran JS, Watson R. Gender differences in substance use and psychiatric distress among medical students: A comprehensive statewide evaluation. Subst Abus. 2017 OctDec; 38(4):401-6.

8. Moher D, Liberati A, Tetzlaff J, Altman DG, Altman D, Antes G, et al. Preferred reporting items for systematic reviews and metaanalyses: The PRISMA statement. PLoS Medicine. 2009.

9. Rivera-Segarra E, Rosario-Hernández E, Carminelli-Corretjer $P$, Tollinchi-Natali N, Polanco-Frontera N. Suicide stigma among medical students in Puerto Rico. Int J Environ Res Public Health. 2018 Jun 29; 15(7):1366-73

10. Alpaslan AH, Avci K, Soylu N, Guzel HI. The Association between Problematic Internet Use, Suicide Probability, Alexithymia and Loneliness among Turkish Medical Students. J Psychiatry. 2014 Sept 5; 18(1):207-214.

11. Sobowale K, Zhou N, Fan J, Liu N, Sherer R. Depression and suicidal ideation in medical students in China: a call for wellness curricula. Int J Med Educ. 2014 Feb 5; 15(5):31-6.
Publish in International Archives of Medicine

International Archives of Medicine is an open access journal publishing articles encompassing all aspects of medical science and clinical practice. IAM is considered a megajournal with independent sections on all areas of medicine. IAM is a really international journal with authors and board members from all around the world. The journal is widely indexed and classified Q2 in category Medicine. 